\title{
Interpersonal Conflict Management Styles and Emotion Self-Management Competencies of Public Accountants
}

\author{
Charlotte Pietersen \\ Department of Business Management, \\ University of Limpopo, Turfloop Campus 0727, Republic of South Africa \\ charlotte.pietersen@ul.ac.za
}

\section{Doi:10.5901/mjss.2014.v5n7p273}

\section{Abstract}

The purpose of the study is to identify the preferred interpersonal conflict management style(s) and level of emotion selfmanagement competencies (emotion expression and emotion regulation) of certified public accountants in the South African context. A cross-sectional design, including a biographical questionnaire, the Thomas-Kilmann Conflict Mode Instrument and selected EQ-Map scales, was utilized to collect data from a convenience sample of respondents. The results show that respondents are able to adapt their conflict management styles to meet the demands of a specific accountant-client relationship. Accountants can also express their emotions when they use one of the more constructive conflict management styles. Their emotional expression is low when they use more destructive conflict management styles. However, they have some limitations in regulating their emotions. This failure to manage negative emotions could impact negatively on the accountant-client relationship. It is recommended that interventions should be implemented by the regulatory body (the CPASA) in South Africa to increase the awareness of certified public accountant. They need to understand the importance and use of conflict management styles and their competency in regulating their emotions constructively have to be enhanced.

Keywords: Public accountants; accountant-client relationship; interpersonal conflict; conflict management styles; emotion selfmanagement competencies

\section{Introduction}

Interpersonal conflict arises when interdependent parties experience negative emotional reactions to a perceived disagreement because they are unable to realize their expectations, goals, wishes and desires (Barki \& Hartwick, 2004: 261; Bell \& Song, 2005). All these elements are present in the accountant-client relationship. Firstly, accounting professionals and their clients are interdependent on one another for the transmission of information (Golen, Catanach \& Moeckel, 1997). Secondly, they and their clients could have conflicting needs, goals and expectations (Conerly \& Tripathi 2004). Thirdly, accounting issues could result in disagreements (See Shampnoi 2005; Zimmerman 2004a; Zimmerman 2004b). Lastly, accounting professionals (and clients) have to deal with underlying negative emotions such as frustration, irritation and anger associated with interpersonal conflict (Meyer 2003; Yew 2005). It is therefore not surprising that various authors (e.g. Cetin, 2004; Isaacs, 1999; Montano, Anes, Hassall, \& Joyce, 2001; Smigla \& Pastoria, 2000) have emphasized that accounting professionals should develop interpersonal conflict management skills.

How a person manages interpersonal conflict is to a large extent dependent on his or her preferred conflict management style(s). Constructive conflict management could result in satisfying interactions, better cooperation and understanding, and increased trust, respect and mutual confidence (Akers \& Porter, 2003; Isaacs, 1999). Conversely, when interpersonal conflict is poorly handled, the outcomes would most probably be mutual antagonism, mistrust, disregard, and even a termination of the accountant-client relationship (Billikopf, 2003; George, 2005).

It is important to be cognisant of the fact that constructive conflict management is not solely dependent on a person's preferred conflict management style(s). A person's competence in dealing with emotions is an essential component of effective conflict management (Salovey \& Grewal, 2005: 72). It is therefore essential the accountants should manage their emotions effectively when they are involved in disagreements with clients (Colon \& Hunt, 2002; Smigla \& Pastoria, 2000).

Empirical research on how effectively different groups of accounting professionals manage interpersonal conflict is relatively scarce. Most studies on conflict management styles tend to targeted auditors (Goodwin, 2002; Brody, Golen \& Reckers, 1998, cited in Goodwin, 2002; Patel, Harrison \& McKinnon, 2002). Empirical research on role of emotion in the accounting profession is also limited (Yew, 2005). In addition, no research has apparently been conducted to explore the 
typical conflict management style(s) of public accountants and their competence in managing their emotions.

The purpose of the present study is to identify the preferred interpersonal conflict management style(s) and emotion self-management competencies of certified public accountants in the South African context and to explore the relationship between their conflict management style(s) and their emotion self-management competencies.

\section{Literature Review}

\subsection{Interpersonal conflict management styles}

Conflict management styles are described in terms of how a person typical responds in interpersonal conflict situations (Ramarajan, Bezrukova, Jehn, Euwema \& Kop, 2004). Most typologies of interpersonal conflict management styles are based on a model developed by Blake and Mouton (1964). They postulated two basic dimensions to differentiate between preferred styles of managing interpersonal conflict, namely, degree of concern for self (high to low), and degree of concern for others (high to low) (Brewer, Mitchell, \& Weber 2002). Concern for self reflects how much emphasis a person places on achieving his or her own goals and concern for others reflects how much value a person places on maintaining good relationships. Combinations of the two dimensions have been used to identify five behavioral categories or typical styles of conflict management (Bao-Yiann \& Chun-Chi, 2012). These modes of behavior are labeled as Collaboration (or Integrating), Compromising, Competing (or Dominating), Accommodating (or Obliging) and Avoiding (De Dreu, Evers, Beersma, Kluwer, \& Nauta, 2001; Lee, 2002; Rahim \& Magner, 1995; Ramarajan et al., 2004). Conflict management scholars consistently identified competing/dominating, accommodating and avoiding as less effective styles and collaboration and compromising as more effective styles for managing interpersonal conflict (Rahim \& Psenicka, 2001; Von Glinow, Shapiro \& Brett, 2004). Furthermore, previous research findings indicated that some individuals have a preferred conflict-handling style, while other are able to adapt their conflict managements styles to the demands of a particular situation (Polkinghorne, 2001).

Collaboration is characterized by high concern for self and high concern for others, and a win-win outcome. Persons who typically use this style place high value on goals and relationships (Lee, 2002). They are likely to be open, to cooperate with others, and to examine differences and exchange information to accomplish an objective (Rahim \& Psenicka, 2001; Rahim \& Magner, 1995). According to Kheel and Zimmerman (2003), Collaboration should be the preferred style for managing accounting issues because both the accountant and client usually prefer a win-win outcome. It is also recommended that this style should be used when accounting issues are complex and when a synthesis of ideas and commitment from the parties involved are needed to resolve the problem or issue (Goodwin, 2002). Shaub, Collins, Holzmann and Lowensohn (2005) found that the greater the accountant's self-concern and concern for his or her client, the less likely he or she is to engage in questionable behaviour.

Compromising incorporates moderate concern for self and for others, and leads to a no win-no loose outcome. Persons who use this style strive to reach consensus. Compromising should be used when the goals of the parties are mutually exclusive, when the parties are equally powerful, and when a win-win solution cannot be reached. From an accounting perspective, it would appear that this style might be appropriate when an issue is less complex but still material (Goodwin, 2002). However, Compromising would be inappropriate when accountants are tempted to use it because they are dependent on service revenues, or when they feel under pressure to meet the needs and expectations of their clients (See Cook, 2005; Deppe, Mano \& Mouritsen, 2005).

Competing includes high concern for self and low concern for others, and results in a win-lose outcome. Research findings suggested this mode is related to the ineffective management of conflict (Rahim \& Psenicka, 2001). In a study on the ethical behavior of management accountants, Shaub et al. (2005) found that the more committed management accountants are to motivated self-interest, the more likely that they would endorse questionable behaviour whether it results in direct payoff to the individual or indirect payoff through manipulating the financial statements. However, the style is useful when there is a lack of direction or when a discussion stalls (Conerly \& Tripathi, 2004). According to Kheel and Zimmerman (2003), Competing might work in accounting disagreements, but skilful persuasion (Integrating/Collaborating and Compromising) is usually more productive.

Accommodating is characterized by low concern for self and high concern for others, and results in a lose-win outcome. Persons who prefer to avoid conflict in favour of harmony tend to use this style. They tend oblige others and to keep their ideas to themselves (Conerly \& Tripathi, 2004; Lee, 2002). The use of Accommodation would mean that the accounting professional has given in to pressure to accept the client's position and this could lead to a compromise of the accountant's independence (Goodwin, 2002).

Avoiding includes low concern for self and low concern for others, and ends in a lose-lose outcome. This style is 
characterized by a tendency to avoid or withdraw from conflict and an indifference to the concerns of both parties involved (Conerly \& Tripathi, 2004; Lee, 2002; Rahim \& Magner, 1995). It is recommended that accounting professionals should not use this style because the disagreement between them and their clients would remain unresolved (Goodwin, 2002).

In the accounting literature the findings of a study by Goodwin (2002) showed that auditors primarily used Collaboration. They used Compromising and Dominating to a lesser extent while the Obliging and Avoiding are rarely used. It could be concluded that success in the accountant-client relationship depends upon the accounting professional's ability to adapt his/her conflict management style(s) to meet the demands of a particular situation. However, accountants who prefer use the two more constructive styles (Collaboration and Compromising) instead of accommodating or avoiding conflict would probably be more effective in most interpersonal conflict situations. Competing should be employed with caution as last resort in situations where the accountant's expertise, and the client need for sound advice, even if the advice is unwelcome, is the deciding factor and not the promotion of self-interest.

\subsection{Emotion self-management}

It is evident from the preceding discussion that the use of a particular conflict management style could have a negative or positive impact on the accountant-client relationships. Another crucial factor that could affect this relationship is the emotion self-management competence of the accounting professional. Emotion management has been identified as a key dimension in managing interpersonal conflict (Gayle \& Preiss, 1998; Jones, 2000; Martin, Knopoff \& Beckman, 1998). The concept of emotion management forms part of Mayer and Salovey's (1997) four-branch model of emotional intelligence. They originally conceptualized the construct of emotional intelligence and defined the concept as a set of four interrelated core dimensions, namely: "...the ability to monitor one's own and other's feeling and emotions, to discriminate among them and to use this information to guide one's thinking and actions, in terms of a person's capacity for recognizing and managing one's own and others' emotions" (Salovey \& Mayer, 1989, p.185). According to Salovey and Grewal (2005: 281), this model provides a useful framework for studying abilities related to processing emotional information. It is also currently the recognized standard for scholarly discourse in the field of emotional intelligence (Van der Zee \& Wabeke, 2004).

Mayer and Salovey's definition distinguishes between cognitive processes for monitoring emotions and discriminating amongst them, and the behavioural process of actually using the information to guide one's thinking and behaviour. Emotion management, the fourth branch of the model, is conceptualized as the behavioral element of emotion (Law \& Wong, 2004; Ogilvie \& Carsky, 2002). It is defined as the ability to manage one's own emotions and the emotions of others (Salovey \& Grewal, 2005: 282).

In the present study the focus in on the first component of emotion management, namely emotion selfmanagement. The decision to focus on this aspect of emotion management is supported by the following argument. According to Colon and Hunt (2002), and Smigla and Pastoria (2000), accounting professionals should manage their emotions when they are involved in disagreements. They should focus in particular on managing their negative emotions when they are involved in interpersonal conflict with their clients. Professional accountants who do not resolve conflict and treat clients as enemies could lose clients (Aquila \& Koltin, 1992). The accounting professional who manages his or her emotions effectively would, most probably, be less likely to lose his or her temper. He/she would manage distressing emotions well, stay composed and positive even in trying moments, and think clearly and stay focused under pressure. He/she would also not become confrontational or avoid conflict (Desivilya \& Yagil, 2005). It would thus appear that the ability manage their emotions would help accountants to perform better in their relationships with their clients (Bay \& McKeage, 2006).

Emotion self-management comprises two elements, namely emotion expression and emotion regulation. People who manage their emotions effectively know how and when to express their emotional reactions and they can effectively regulate their mood states (Desivilya \& Yagil, 2005; Law \& Wong, 2004; Kirch, Tucker \& Kirch, 2001; Salovey, Bedell, Detweiler \& Mayer, 1999: 161). Mayer and Salovey (1997) described emotion expression as the ability to be able to express emotions accurately to others. A more comprehensive definition of emotion expression is provided in the EQ Map Manual. In the manual emotion expression is described as "...the degree to which a person can express his/her feelings, allowing them to be used as an integral part of his/her daily actions and interactions... and explores your ability to verbalized emotions in a way that puts this information to productive use." (Q-Metrics, 1997a: 6).

Emotion regulation on the other hand refers to a person's ability to keep negative emotions, such as anger, frustration or hostility, and other disruptive emotion associated with conflict under control (Bar-On \& Parker, 2000; Goleman, Boyatzis \& McKee, 2002; Jordan \& Troth, 2004; Taylor, 2001). Goleman (2001) described emotion regulation 
is the ability to regulate distressing affects like anxiety and anger, and to inhibit emotional impulsivity. Is also reflects an individual's ability to connect or disconnect from an emotion depending on its usefulness in any given situation (Mayer \& Salovey, 1997). In the EQ Map Manual the term constructive discontent (emotion regulation) is described as "...your ability to stay calm and focused and emotionally grounded even in the face of disagreement or conflict" (Q-Metrics, 1997a:12). According to Martin et al. (1998), emotional regulation is considered a prerequisite for maintaining interpersonal relationships.

The relationship between the broader concept of emotional intelligence and conflict management styles was illustrated in a study conducted by Yu, Sardessai, Lu and Zhao (2006). The findings of their study showed that there is a positive relationship between employed MBA students' emotional intelligence and Integrating, Compromising, and surprisingly, Competing. The importance of emotion self-management in the accounting profession was highlighted by the following research findings. Boyatzis (1999) assessed partners in a multinational accounting firm on emotional competencies. The findings of their study showed that senior partners with strength in emotion self-management consistently contributed higher levels of profitability when compared to their colleagues.

However, according to the CMIA (2001), professional accountants, out of all professions, have the lowest emotional intelligence. With regard to the second component of emotion management (managing the emotions of others) research findings showed that most accountants are insensitive to the emotions of others (Accountancy Ireland, 2000). Furthermore, whilst they have the necessary technical abilities to be successful, they have trouble expressing their emotions in interactions (Cory, 1992; Enis, 1998). They are also not particularly interested in analyzing and understanding emotions (Gomples 1990). However, it would appear that some groups of accountants at least are able to regulate their emotions. The typical chartered accountant, for example, is calm, even-tempered and controlled (Gomples, 1990).

To conclude, in interpersonal conflict situations accounting professional have to manage their negative emotional reactions and employ constructive conflict management styles to resolve interpersonal issues with their clients. In fact, it could be expected that the probability of effective conflict resolution would be enhanced if accountants focus on the use of logic, if they remains objective, and when they retain their own emotional equilibrium (Deppe et al., 2005, Mann, 2004; George, 2005). Staying calm, particularly when the client is emotional, is also critical to fostering a climate that enhances communication. The reason for this is that when an accounting professional '... get excited, the client will too, and nobody wins' (Journal of Accountancy, 1998: 10).

It could thus be hypothesized that the professional accountant who is low on emotion self-management would tend to use the Competing, Accommodating or Avoiding in interpersonal conflict situations. Anger control is significantly associated with and predicted the conflict management styles (Gündüz, Tunç \& İnandi,2013). On the other hand, accounting professionals who are able to manage their emotions effectively would probably use more constructive conflict management styles (Collaboration or Compromising).

\section{Method}

\subsection{Population and Sample}

A cross-sectional survey design was used to collect data on the conflict management styles and emotion selfmanagement from the target population within relatively a short time frame. This type of design is commonly used for cross-sectional data gathering at a single point of time (Bailey, 1982; Fife-Shaw, 1997).

Data was gathered in cooperation with the Institute of Certified Public Accountants of South Africa (CPASA) (formerly known as the Institute of Commercial and Financial Accountants of South Africa). The Institute is the second largest accounting institute in South Africa and is representative of practice types included in public accounting. Although all the members of the Institute were invited to participate in the research project, only 225 opted to take part in the study.

Each respondent received (a) a cover letter that explained the purpose of the survey, (b) a biographical questionnaire, (c) the Thomas-Kilmann Conflict Mode Instrument (TKI) and (d) the selected EQ-Map scales, via e-mail. They were invited to participate and were informed that their participation was voluntary. They were assured that all information would be kept strictly confidential and that the individual identities of respondents (in the unlikely event that it may become known) would be protected at all times. They were also informed that the questionnaire data (grouped responses) would be statistically analysed and the research findings would be disseminated for research purposes only. The completed questionnaires were sent back electronically. 


\subsection{Instrumentation}

The TKI was administered to identify the conflict management styles of the target group. In the TKI the terms collaborating, accommodating and competing is used instead of integrating, obliging and dominating (Thomas, 1976). Kilmann and Thomas (1977) consider low social desirability contamination as one of the strengths of the TKI. Their research findings provided reasonable support for the validity of their questionnaire. Internal consistency coefficients are in the moderate range (average Cronbach alpha $=0.60$ ) and test-retest reliability range from $0.61-0.68$. These findings suggest that the instrument is useful to differentiate between conflict management styles. Subsequent research also provided support for the psychometric properties of the TKI (Galon, 2005; Margavio Hignite \& Chin, 1999; Rahim, 2001).

Two of the subscales of the EQ Map (Version 4.5) provide a behavioural assessment of emotion self-management. Scale 4 is used to assess emotional expression and Scale 10 provides an assessment of emotional regulation or constructive discontent (Q-Metrics, 1997a). Other available instruments, such as the MESCEIT, are used to measure personality characteristics or traits and knowledge of emotions instead of assessing behavioural dimensions of emotional intelligence (Van der Zee \& Wabeke, 2004).

The EQ Map is a self-report instrument developed by Cooper and Sawaf (1997). The instrument covers areas that are broader than just emotional intelligence. It is a five part "personal discovery" of current environment, emotional awareness, emotional competencies, emotional values and attitudes and outcomes (Gowing, 2001). Respondents rate how well statements describe their current behaviour on a four-point Likert type scale. The instrument has been extensively researched, was norm tested and is regarded as a statistically reliable measurement that allows an individual to chart strengths and vulnerabilities on a number of emotional intelligence components (Q-Metrics, 1997b:1). According to Martin (2004), the reliability of the instrument is good. In fact, in would appear that reliability coefficients for all the subscales are above 0.85 (Poon, Othman, Anugerah \& Sari, 2002).

\subsection{Data analysis}

The data were entered into the Statistical Package for Social Sciences (SPSS v. 18.0). Descriptive statistics (percentages) were calculated for the biographical data. Means and standard deviations were calculated to identify preferred conflict management styles and to analyse levels of emotional self-management competence. Pearson's product-moment correlation coefficient (one-tailed test) was calculated to determine the strength and direction of the relationships between the five conflict management style scores and scores on emotion expression and emotion regulation (significant levels $=0.01$ and 0.05 ). Pearson's $r$ was chosen because scores TKI and EQ-Map scales represent interval scales of measurement.

\section{Findings}

\subsection{Sample composition}

Table 1 shows that gender distribution of the respondents. In Table 2 the ages of the respondents are given. Table 3 represents their marital status. Table 4 shows the population groups of the respondents. Table 5 provides an indication of how long they have been working as certified public accountants.

Table 1: Gender of respondents

\begin{tabular}{|l|c|c|c|}
\hline \multicolumn{1}{|c|}{ Gender } & Frequency & Percentage \\
\hline$\square$ & Male & 120 & 53.3 \\
\hline$\square$ & Female & 105 & 46.7 \\
\hline$\square$ & Total & 225 & 100.0 \\
\hline$\square$
\end{tabular}

The following is evident from Tables 1 to 5 : Although more male respondents participated in the study, the participants were relatively equally distributed in terms of gender. Most of the respondents (46.7\%) fall in the age group 31 to 40 years. The majority of respondents (77.3\%) are married. Most of the respondents are white (92\%) and accountants of 
colour (8\%) are underrepresented in the sample. Approximately half of the respondents have been working in the profession for less than 10 years and the other half for more than 10 years.

Table 2: Age of respondents

\begin{tabular}{|c|c|c|}
\hline Age & Frequency & Percentage \\
\hline $20-30$ & 21 & 9.3 \\
\hline $31-40$ & 105 & 46.7 \\
\hline $41-50$ & 63 & 28.0 \\
\hline $51+$ & 36 & 16.0 \\
\hline Total & 225 & 100.0 \\
\hline
\end{tabular}

Table 3: Marital status of respondents

\begin{tabular}{|c|c|c|}
\hline Marital status & Frequency & Percentage \\
\hline Single & 21 & 9.3 \\
\hline Married & 174 & 77.3 \\
\hline Divorced & 18 & 8.0 \\
\hline Widowed & 12 & 5.3 \\
\hline Total & 225 & 100.0 \\
\hline
\end{tabular}

Table 4: Population group of respondents

\begin{tabular}{|c|c|c|c|}
\hline & Population group & Frequency & Percentage \\
\hline & African & 9 & 4.0 \\
\hline & Asian & 6 & 2.7 \\
\hline & Coloured & 3 & 1.3 \\
\hline & White & 207 & 92.0 \\
\hline & Total & 225 & 100.0 \\
\hline
\end{tabular}

Table 5: Number of years working as a certified public accountant

\begin{tabular}{|c|c|c|c|}
\hline & Number of years & Frequency & Percentage \\
\hline & 5 and less & 60 & 26.7 \\
\hline & 6 to10 & 51 & 22.7 \\
\hline & 11 to 15 & 57 & 25.3 \\
\hline & $16+$ & 57 & 25.3 \\
\hline & Total & 225 & 100.0 \\
\hline
\end{tabular}

In Table 6 the types of clients to whom respondents provide services are listed. It is evident from Table 6 that the respondents provide services to a wide variety of clients and that most of the respondents provide services to closed corporations (86.7\%) and individual clients (81.3\%). 
Table 6: Clients to whom services are provided

\begin{tabular}{|l|c|}
\hline 1. SMME's & $34(57.3 \%)$ \\
\hline 2. Partnerships & $40(53.3 \%)$ \\
\hline 3. Individuals & $61(81.3 \%)$ \\
\hline 4. Close corporations & $65(86.7 \%)$ \\
\hline 5. Companies & $41(54.7 \%)$ \\
\hline 6. Schools & $17(22.75)$ \\
\hline 7. Micro Finance Regulatory Council & $9(12 \%)$ \\
\hline 8. Other entities: Non-profitable; Sectional title; Trusts & $25(33.3 \%)$ \\
\hline
\end{tabular}

The types of services provided by the respondents to clients are specified in Table 7. The results in Table 7 show that the three main groups of services the respondents provide to clients are: tax services (89.3\%), accounting and secretarial services (86.7\%), and financial services (78.7\%).

Table 7: Types of services provided

\begin{tabular}{|l|c|}
\hline 1. Accounting and secretarial & $65(86.7 \%)$ \\
\hline 2. Financial & $59(78.7 \%)$ \\
\hline 3. Tax & $67(89.3 \%)$ \\
\hline 4. Investment advise & $14(18.7 \%)$ \\
\hline 5. Commissioner of Oaths & $35(46.7 \%)$ \\
\hline 6. Management consultancy & $31(41.35)$ \\
\hline 7. Compliance officers/reports & $25(33.3 \%)$ \\
\hline 8. Information technology & $20(26.7)$ \\
\hline 9. Management accounting & $45(60 \%)$ \\
\hline 10. Corporate finance & $16(21.3 \%)$ \\
\hline 11. Forensic accounting & $9(12 \%)$ \\
\hline 12. Insolvency & $15(20 \%)$ \\
\hline
\end{tabular}

\subsection{Conflict management styles}

Table 8: Conflict management styles

\begin{tabular}{|c|c|c|c|c|c|}
\hline & Style 1 & Style 2 & Style 3 & Style 4 & Style 5 \\
\hline Mean & 7.00 & 6.9 & 4.47 & 7.00 & 5.36 \\
\hline Std. Deviation & 1.94 & 2.30 & 2.47 & 1.99 & 2.39 \\
\hline
\end{tabular}

The means and standard deviations for each of the five conflict management styles are provided in Table 8. The highest possible score for each style is 12 . In the table conflict management styles are represented as follows: Style 1: Collaboration; Style 2: Compromising; Style 3: Competing; Style 4: Avoiding; Style 5: Accommodating.

The results in Table 8 show that respondents' preference for different conflict management styles are relatively equally distributed. 


\subsection{Emotion self-management}

In Table 9 the means and standard deviations for emotion expression and emotion regulation scores for the sample of respondents are represented.

It is evident from Table 9 that the respondents' average on emotion expression is 18.5 and their average score on emotion regulation is 16.88. A score of 18 to 22 represents proficiency (steady, balanced effectiveness) in emotional expression in most situations (Q-Metrics, 1997a: 2; Q-Metrics 1997b: 7). On the other hand, a score of 16 to 20 indicates inconsistent, unsteady and fluctuating effectiveness in emotion regulation (Q-Metrics, 1997a: 2; Q-Metrics 1997b: 11). It would thus appear that they are able to express their emotions but that they are not always able to regulate their emotions effectively.

Table 9: Emotion self-management

\begin{tabular}{|c|c|c|}
\hline \multicolumn{1}{|c|}{} & Emotion Expression & Emotion Regulation \\
\hline Mean & 18.50 & 16.88 \\
\hline Std. Deviation & 3.05 & 2.19 \\
\hline
\end{tabular}

\subsection{Relationship between conflict management styles and emotion self-management}

Table 10 provides an inter-correlation matrix of the relationships between the following variables: the five conflict management styles, and emotion expression and emotion regulation.

Table 10: Inter-correlation matrix of conflict management styles, emotion expression and emotion regulation

\begin{tabular}{|c|c|c|c|}
\hline & & Emotion expression & Emotion regulation \\
\hline \multirow{2}{*}{ Style 1} & Pearson Correlation & $.292(\star \star)$ & .129 \\
\hline & Sig. (1-tailed) & .008 & .147 \\
\hline \multirow[t]{2}{*}{ Style 2} & Pearson Correlation & .110 & .121 \\
\hline & Sig. (1-tailed) & .187 & .163 \\
\hline \multirow[t]{2}{*}{ Style 3} & Pearson Correlation & .198 & -.135 \\
\hline & Sig. (1-tailed) & .051 & .135 \\
\hline \multirow[t]{2}{*}{ Style 4} & Pearson Correlation & $-.252\left(^{*}\right)$ & -.122 \\
\hline & Sig. (1-tailed) & .019 & .161 \\
\hline \multirow[t]{2}{*}{ Style 5} & Pearson Correlation & $-.311(* *)$ & -.111 \\
\hline & Sig. (1-tailed) & .005 & .184 \\
\hline
\end{tabular}

** Correlation is significant at the 0.01 level (1-tailed).

* Correlation is significant at the 0.05 level (1-tailed).

The following is evident from the Table 10:

- There is a highly significant positive relationship between Collaboration (Style 1) and emotion expression.

- There is a significant negative relationship between Avoiding (Style 4) and emotion expression.

- There is a highly significant negative relationship between Accommodating (Style 5) and emotion expression.

- There are no significant relationships between Competing (Style 3) and Compromising (Style 2), and emotion expression and emotion regulation.

- There are no significant relationships between any of the five conflict management styles and emotion regulation. 


\section{Discussion and Conclusion}

Successful conflict resolution in the accountant-client relationships depends, to a large extent, upon accounting professionals' ability to adapt their interpersonal conflict management style(s) to meet the demands of a particular situation. The findings of the present study showed that respondents have no clear preference for a particular conflict management style. This means that they are probably able to adapt their style of conflict management from situation to situation.

This does not automatically guarantee that they would use the most appropriate style to meet the demands of a specific situation. The findings also indicated that respondents employ Accommodation and Avoidance in their interaction with their clients. Accountants should not compromise their independence by accommodating a client and giving in to pressure to accept the client's position. They are also obliged resolve conflict instead of showing indifferent to their concerns and the concerns of their clients by avoiding or withdrawing for conflict. In the long run unresolved conflict could result in a discontinuation of the accountant-client relationship. Competing should be employed with caution as last resort in situations where the accountant's expertise, and the client need for sound advice, even if the advice is unwelcome, is the deciding factor and not the promotion of self-interest.

It is important that accounting professionals should be made aware of the advantages and disadvantages of using different styles of conflict management in their relationships with their clients. In general, they should be encouraged to use the two more constructive styles (Collaboration and Compromising) as is recommended in the literature.

As indicated previously a person's competence in dealing with emotions is an essential component of effective conflict management. The findings of the present study show that respondents are in general proficient in expressing their emotions. This finding contradicts previous research findings by Cory (1992) and Enis (1998) that accountants do no express their emotions in interactions. It would appear that emotions are clearly expressed when respondents use Collaboration, while there is no clear link between emotion expression and the other recommended conflict management styles (Compromising). Emotions are not expressed when Avoiding or Accommodating are used.

However, the findings suggest that respondents are not always able to regulate their emotions effectively. Although there is no significant relationship between interpersonal conflict management styles and emotion regulation, there is a possibility that the respondents may not be able to inhibit emotional impulsivity. They may misinterpret a situation and choose ineffective strategies to manage conflict (Cole \& Rozzell, 2011). This is disheartening in light the statement by Martin et al. (1998) that emotion regulation is a prerequisite for maintaining interpersonal relationships. In an ever increasing competitive environment no accountant could afford to lose a client. If an accountant express negative emotions, such as anger or frustration, in an uncontrolled manner while interacting with a client it could impact negatively on their relationship in the long run.

It could be concluded that although respondents are able to use different styles to manage conflict, the accountantclient relationship could still suffer negative consequences if accountants are unable to regulate their emotions. In it therefore of critical importance to increase certified public accountants' awareness of and in skill in emotion regulation. Fortunately emotional competence can be developed. It is recommended that the bodies responsible for the continuous development of certified public accountants should seriously consider the implementation of development programmes to develop the emotion regulation skills of their members. It is also recommended that developmental programmes should be initiated to increase their awareness of the importance of and skill in interpersonal conflict management.

The investigation has lead to recommendations regarding the development of constructive conflict management styles and skill in emotion self-management of certified public accountants in South Africa to help them to effectively manage accountant-client conflict episodes. The low response rate and the use of a convenience sample might limit the generalizability of the findings. More research is needed to confirm the findings of the study.

\section{References}

Accountancy Ireland (2000). Cyber sightings. Accountancy Ireland, 32 (5): 33-35.

Akers, M.D. \& Porter, G.L. (2003). Your EQ skills: got what it takes? Journal of Accountancy, 195 (3): 65-69.

Aquila, A.J. \& Koltin, A.D. (1992). How to loose clients without really trying. Journal of Accountancy, May: 67-70.

Bailey, K. D. (1982). Methods of social research. (2nd Ed). London: Collier Macmillan.

Bao-Yiann, A. \& Chun-Chi, Y. (2012). The moderating role of personality traits on emotional intelligence and conflict management styles. Psychological Reports, 110 (3): 1021-1025.

Barki, H. \& Hartwick, J. (2004). Conceptualizing the construct of interpersonal conflict. International Journal of Conflict Management, 15 (3): 216 245.

Bar-On, R. \& Parker. J. D. A. (Eds.) (2000). The handbook of emotional intelligence. San Francisco: Jossey-Bass. 
Bay, D. \& McKeage, K. (2006). Emotional Intelligence in undergraduate accounting students: preliminary assessment . Accounting Education, 15 (4): 439-454.

Bell, C. \& Song, F. (2005). Emotions in the conflict process: an application of the cognitive appraisal model of emotions to conflict management. International Journal of Conflict Management, 16 (1): 30-54.

Blake, R. \& Mouton, J. (1964). The managerial grid. Houston, TX: Gulf.

Blanthorne, C., Bhamornsiri, S. \& Guinn, R.E. (2005). Are technical skills still important? [online] Available: http://www.nysscpa.org/cpajournal /2005/305/essentials/p64.htm

Biilikopf, G. (2003). Conflict management skills. Labor Management in Agriculture: Cultivating Personnel Productivity, 209: 157-174.

Boyatzis, R. (1999). The financial impact of competencies in leadership and management of consulting firms. Department of Organizational Behavior Working Paper, Case Western Reserve University, Cleveland.

Brewer, N., Mitchell, P. \& Weber, N. (2002). Gender role, organizational status, and conflict management styles. International Journal of Conflict Management, 13 (1): 78-94.

Cetin, M.O. (2004). Conflict management styles: a comparative study of university academics and high school teachers. The Journal of American Academy of Business, September: 325-332.

Cole, A. Y. \& Rozell, E. (2011). Emotional intelligence and impression management: a theoretical framework. Insights to a Changing World Journal, 1: 93-114.

Colon, D.E. \& Hunt, C.S. (2002). Dealing with feeling: the influence of outcome representations on negotiation. International Journal of Conflict Management, 13 (1): 38-58.

CMIA (2001), Emotional intelligence. [online] Available: www.cimaglobal.com.

Conerly, K. \& Tripathi, A. (2004). What is your conflict style? Understanding and dealing with your conflict style. The Journal of Quality and Participation, Summer: 16-20.

Cook, J.M. (2005). Happy people, happy clients. Journal of Accountancy, 200 (4): 38.

Cooper, R. \& Sawaf, A. (1997). Executive EQ. London: Orion Books.

Cory, S. N. 1992. Quality and quantity of accounting students and the stereotypical accountant: Is there a relationship? Journal of Accounting Education 10 (1): 1-24.

Desivilya, H.S. \& Yagil, D. (2005). The role of emotions in conflict management: the case of work teams. International Journal of Conflict Management, 6 (1): 55-69.

De Dreu, C.K.W, Evers, A., Beersma, B., Kluwer, E. \& Nauta, A. (2001). A theory-based measure of conflict management strategies in the workplace: Journal of Organizational Behavior, 22, 645-668.

Deppe, L.A., Mano, R.M. \& Mouritsen, M. (2005). Don't shrink from the challenge; stand up and do what's right. CPA Journal, 75 (3): 6-10.

Enis, C. R. 1998. The effect of gender on role perceptions of accountants: twenty years through the looking glass. Advances in Public Interest Accounting, 7: 107-138.

Fife-Schaw. (1997). Surveys and sampling issues. In Breakwell, G. M., Hammond, S. \& Fife-Schaw, C. (Eds). Research methods in psychology. London: Sage.

Fish, M. \& Galon, V. (2005). Leadership style and choice of in conflict management among Israeli nurse managers in general hospitals. Journal of Nursing Management, 13: 137-146.

Frederick, M.L. (2002). The personality factor in accounting success. The accounting Review: 400-404.

Friedman, R.A., Tidd, S.T., Currall, S.C. \& Tsai, J.C. (2000). What goes around comes around: the impact of personal conflict management style on work conflict and stress management. The International Journal of Conflict Management, 11 (1): 32-51.

Gayle, B. M. \& Preiss, R. W. (1998). Assessing emotionality in organizational conflicts. Management Communication Quarterly, 12: 280-302.

George, L.F. (2005). Resolving conflict through behavior modification. CPA Journal, 75 (10): 60-61.

Golen, S.P., Catanach, A.H. \& Moeckel, C. (1997). The frequency and seriousness of communication barriers in the auditor-client relationship. Business Commnication Quarterly, 60 (3): 25-37.

Goleman, D. (2001). An El-based theory of performance. In Cherniss, C. \& Goleman, D. (Eds.). The emotionally intelligent workplace. [online] Available: www.eiconsortium.org

Goleman, D., Boyatzis, R, \& McKee, A. (2002). The New Leaders. Boston: Harvard Business School Press.

Gomples, S. (1990). Accountants 'conformist and unemotional'. Accountancy; 105 (1158): 13-17.

Goodwin, J.A. (2002). Auditors' conflict management styles: an exploratory study. Abacus, 38 (3): 378-410

Gowing, M. K. (2001). Measurement of individual emotional competence. In C. Cherniss \& D. Goleman (Eds.). The Emotionally Intelligent Workplace, (pp. 83-131). San Francisco, CA: Jossey-Bass.

Gündüz, B., Tunç, B. \& Inandi, Y. (2013). The relationship between the school administrators' anger control and stress coping methods and their conflict management style. International Journal of Human Sciences, 10 (1): 641-660.

Hignite, M.A., Margavio, T.M. \& Chin, J.M. (1999). Assessing the conflict resolution profiles of emerging information systems professionals. Journal of Information Systems Education, 13(4): 315-323.

Isaacs, H.M. (1999). The CPA negotiator: The next step. CPA Journal, 69 (9): 52-53.

Jones, T. S. (2000). Emotional communication in conflict: Essence and impact. In W. Eadie \& P. Nelson (Eds.), The language of conflict and resolution (pp. 81-104). Thousand Oaks, CA: Sage.

Jordan, P.J \& Troth, A.C. (2004). Managing emotions during team problem solving: Emotional intelligence and conflict resolution. Human Performance, 17(2): 195-218.

Journal of Accountancy, (1998). Communication with clients. Journal of Accountancy, 186 (5): 10.

Kheel, T.W. \& Zimmerman, P. (2003). The gentle art of agreement making. CPA Journal, 73 (3): 57.

Kirch, D.P., Tucker, M.L. \& Kirch, C.E. (2001). The benefits of emotional intelligence in accounting firms. CPA Journal, 71 (8): 60-61.

Kilmann, R.H. \& Thomas, K.W. (1977). Developing a forced-choice measure of conflict-handling behavior: the "MODE" instrument. Educational and Psychological Measurement, 37, 309-325.

Law, K.S. \& Wong, C. (2004). The construct and criterion validity of emotional intelligence and its potential utility for management studies. Journal 
of Applied Psychology, 89 (3); 483-496.

Lee, C. (2002). Referent role and styles of handling interpersonal conflict: evidence from a national sample of Korean local government employees. International Journal of Conflict Management, 13 (2): 127-141.

Mann, S. (2004). 'People-work': Emotion management, stress and coping. British Journal of Guidance and Counselling, 32 (2): 205-221.

Martin, J., Knopoff, K. \& Beckman, C. (1998). An alternative to bureaucratic impersonality and emotional labor: bounded emotionality at The Body Shop. Administrative Science Quarterly, 43: 429-469.

Martin, J. S. (2004). The emerging role of emotional intelligence in business communication classes. Proceedings of the 2004 Association for Business Communication Annual Convention. Association for Business Communication: 87-93. [online] Available:

http://www.businesscommunication.org/conventions/Proceedings/2004/PDFs/09ABC04.PDF.

Mayer, J. \& Salovey, P. (1997). What is emotional intelligence?, in P. Salovey \& D. Sluyter (Eds.), Emotional development and emotional intelligence: Implications for educators, Basic Books, New York, pp. 3-31.

Meyer, E. (2003). How to avoid debt-related conflict. Chartered Accountants Journal, 82 (2): 20-21.

Montano, J.L.A., Anes, J.A.D., Hassall, T. \& Joyce, J. (2001). Vocational skills in the accounting professional profile: the Chartered Institute of Management Accountants (CIMA) employers' opinion. Accounting Education, 10 (1): 299-313.

Ogilvie, J.R. \& Carsky, M.L. (2002). Building emotional intelligence in negotiations. International Journal of Conflict Management, 13 (4): $381-400$.

Patel, C., Harrison, L. \& McKinnon, J. L. (2002). Cultural influences on judgments of professional accountants in auditor-client conflict resolution. Journal of International Financial Management \& Accounting, 13 (1), 1-31.

Polkinghorne, B.B.S. (2001). Between war and peace: an examination of conflict management in four conflict zones. International Journal of Conflict Management, 12 (1): 23-46.

Poon, J. M. L., Othman, A. S. \& Sari, R. A. (2002). Effects of emotional intelligence and career commitment on career success. Malaysian Management Review, 37(1): 46-52.

Qmetrics. (1997a). EQ Map interpretation guide. Version 4.5. Essi Systems Inc.:San Francisco.

Qmetrics. (1997b). Mapping your emotional intelligence. Essi Systems Inc.:San Francisco. Rahim, M.A. (2001). Managing conflict in organizations (3rd Ed.). New York: Quorum Books.Rahim, M.A.D. \& Bonoma, T.V. (1979). Managing organizational conflict: a model for diagnosis and intervention. Psychological Reports, 44: 1323-1344.

Rahim, M.A.D. \& Magner, N.R. (1995). Confirmatory factor analysis of the styles of handling interpersonal conflict: first order factor model and its invariance across groups. Journal of Applied Psychology, 80 (1): 122-132.

Rahim, M.A.D. \& Psenicka, C. (2001). A structural equation model of leader power, subordinates' styles of handling conflict, and job performance. International Journal of Conflict Management, 12 (3): 191-211.

Ramarjan, L, Bezrukova, K, Jehn, K.A., Euwema, M. \& Kop, N. (2004). Relationship between peacekeepers and NGO workers: the role of training and conflict management styles in international peacekeeping. International Journal of Conflict Management, 15 (2): 167-191.

Salovey, P., Bedell, B.T., Detweiler, J.B. \& Mayer, J.D. (1999). Coping intelligently: emotional intelligence and the coping process. In C.R. Snyder (Ed.), Coping: The psychology of what works (pp. 141-164). New York: Oxford Psychology Press.

Salovey, P. \& Grewal, D. (2005). The science of emotional intelligence. Current Directions in Psychological Science, 14 (6): $281-285$.

Salovey, P. \& Mayer, J. D. (1989). Emotional intelligence. Imagination, Cognition, and Personality, 9: 185-211.

Sanders, J.C \& Fulks, D.L. (1995). Stress and stress management in public accountants. CPA Journal, 65 (8): $46-49$.

Schwartz, A.E. (1997). How to handle conflict. CPA Journal, 66 (4): $72-73$.

Shampnoi, E. (2005). The arbitrator selection process and new ethical standards. CPA Journal, 75 (12): 60-62.

Shaub, M.K., Collins, F. Holzmann, O. \& Lowensohn, S.H. (2005). Self-interest vs. concern for others. Strategic Finance, 86 (9): $41-46$.

Smigla, J.E. \& Pastoria, G. (2000). Emotional intelligence: Some have it, others can learn. CPA Journal, 70 (6): 60-61.

Taylor, G.J. (2001). Low emotional intelligence and mental illness. In J. Ciarrochi, \& J.P. Forgas (Eds), Emotional intelligence in everyday life: A scientific enquiry (pp. 67-81). Philadelphia, PA: Taylor \& Francis.

Thomas, K.W. (1976). Conflict and conflict management. In M.D. Dunnette (Ed.), Handbook of industrial and organizational psychology (pp. 889935). Chicago: Rand McNally.

Thomas, K.W. \& R.H. Kilmann. (1974).Thomas-Kilmann Conflict Mode Instrument. Consulting Psychologists Press, Inc., Palo Alto, CA.

Turner, L. (2004). Emotional intelligence - our intangible asset? Chartered Accountancy Journal: 29-31.

Van der Zee, K. \& Wabeke, R. (2004). Is trait emotional intelligence simply or more than just a trait? European Journal of Personality, 18: $243-$ 263.

Von Glinow, M. A., Shapiro, D. L. \& Brett, J. M. (2004). Can we talk, and should we? Managing emotional conflict in multicultural teams. Academy of Management Review, 29 (4): 578-592.

Whatley, P. (2005). Easing into interviews. Internal Auditor. 25-26.

Yew, M.C. (2005). Job offers of multi-national accounting firms: The effects of emotional intelligence, extra-curricular activities, and academic performance. Accounting Education, 14 (10: 75-93.

Yu, C., Sardessai, J. L. \& Zhao, J. (2006). Relationship of emotional intelligence with conflict management styles: and empirical study in China. International Journal of Management and Enterprise Development (IJMED), 3 (1/2): 19-29.

Zimmerman, P. (2004a). Current trends in dispute resolution. CAP Journal, 74 (10):12.

Zimmerman, P. (2004b). Mediating the dissolution of a firm. CPA Journal, 75 (3): 67. 